\title{
Resulted in Prolongation of Hospitalization
}

National Cancer Institute

\section{Source}

National Cancer Institute. Resulted in Prolongation of Hospitalization. NCI Thesaurus.

Code C102450.

An indication or description that an extended period of hospitalization is necessary. 